\title{
9
}

\section{STEP BY STEP \\ The insidious evolution of Australia's asylum seeker regime since 1992}

\author{
Savitri Taylor ${ }^{1}$
}

I have been thinking and writing about Australia's asylum seeker policies for over 25 years. When I started back in 1991, the asylum seeker policies now espoused by the major parties would have been inconceivable to most politicians on all sides - but here we are. Explaining how we got here requires me to start further back in time than 1991. It requires me to start, in fact, with the drafting of the founding document of the Australian political and legal system - the Constitution. From there, I consider two key features of contemporary asylum seeker policy - mandatory detention, which was introduced in 1992, and offshore processing, which was initially introduced in 2001. I end the chapter by reflecting on the lessons of our past for our future.

1 Associate Professor, Law School, La Trobe University. Part of this chapter is based on Savitri Taylor, 'How Did We Get Here? A Reflection on 25 Years of Australian Asylum Seeker Policy', Law and Justice: La Trobe Law School Blog, 25 February 2016, available at: law.blogs.latrobe.edu. $\mathrm{au} / 2016 / 02 / 25 /$ how-did-we-get-here-a-reflection-on-25-years-of-australian-asylum-seeker-policy/. Other parts of the chapter are based on earlier articles of mine as cited. 


\section{The original sin}

The Australian obsession with immigration and border control pre-dates Federation, with a major motivator for Federation being the desire to achieve uniformity in such control across the Australian continent. ${ }^{2}$ Constitutional enshrinement of parliament's unqualified power to legislate with respect to 'naturalization and aliens' ${ }^{3}$ and 'immigration and emigration' ${ }^{3}$ was taken as a matter of course through all the constitutional conventions from $1891 .{ }^{5}$ By contrast, proposals made at those conventions to include due process and equal protection clauses in the Constitution were fervently and successfully opposed. ${ }^{6}$ As Eve Lester explains in her excellent book, Making Migration Law, rejection of such clauses was:

intended to ensure that the Commonwealth could discriminate on account of race and colour. This purpose is articulated by a number of delegates during the constitutional conventions, including Sir John Forrest and (most doggedly) Isaac Isaacs. Other delegates made clear their concerns that above all the provision should not prevent discrimination against non-Europeans. ${ }^{7}$

This was the original sin.

\section{Mandatory detention}

Julie Macken identifies the introduction of mandatory detention by the Labor Government as 'the stone that began the avalanche'. ${ }^{8}$ Looking back over 25 plus years, I agree. What particularly struck me as I was reading Macken's piece was a quote from Neal Blewett's memoir, A Cabinet Diary. Neal Blewett, who was then minister for social security, had a meeting on

2 Mary Crock and Laurie Berg, Immigration, Refugees and Forced Migration: Law, Policy and Practice in Australia (Sydney: Federation Press, 2011), 24-26.

3 Australian Constitution, s 51(xix).

4 Ibid., s 51(xxvii).

5 Eve Lester, Making Migration Law: The Foreigner, Sovereignty, and the Case of Australia (Cambridge: Cambridge University Press, 2018), 115.

6 Ibid., 116.

7 Ibid.

8 Julie Macken, 'The Long Journey to Nauru', New Matilda, 12 January 2016, available at: newmatilda.com/2016/01/12/the-long-journey-to-nauru/. 
30 March 1992 with Peter Staples, then the minister for aged, family and health services, and Gerry Hand, then the minister for immigration. In his diary entry about the meeting, Blewett said:

A 9 pm meeting with Hand and Staples on the asylum-seekers' benefit. Hand wanted nothing to do with any ameliorative stance. He was for interning all who sought refugee status in camps, mostly at Port Hedland, where they would be fed and looked after. This is a nonsensical proposal - politically unsellable to the liberal constituency, impossible in practice (if any significant number of refugees took up the option his department would collapse) and financially irresponsible - if it worked it would cost more than the other options. It was obviously [Hand's] intention that if Staples provided an asylum-seekers' benefit, or I the charity option or a modified asylum-seekers' benefit, we would have to take responsibility for the measure. His left-wing mate Staples accused Hand of 'abdicating responsibility for his own shit'. So Staples and I decided to call his bluff and accept his lead as Immigration Minister. It will be interesting to see the cabinet response to his proposals. ${ }^{9}$

What Macken does not mention in her piece is that mandatory detention as we know it today was not introduced all at once; it was introduced bit by bit. In late 1989, Australia started experiencing its second wave of people arriving by boat (mostly Cambodian nationals). There were changes made to the Migration Act 1958 (Cth) in 1989 that allowed immigration officials to detain 'illegal entrants' (as they were called at the time) until their immigration status was resolved and, as a matter of administrative policy, that is what happened. The next step was the one foreshadowed by Gerry Hand in his meeting with Blewett and Staples. In May 1992, the Labor Government, with the support of the Coalition, procured the passage of the Migration Amendment Act 1992 (Cth). This legislation labelled the unauthorised boat arrivals as 'designated persons' and provided for their mandatory detention. In his second reading speech, Gerry Hand said that the legislation was 'only intended to be an interim measure' and was designed 'to address only the pressing requirements of the current situation'. ${ }^{10}$ That original legislation also imposed a 273-day limit on the duration of detention, though there were circumstances in which the clock would stop ticking.

9 Neal Blewett, A Cabinet Diary: A Personal Record of the First Keating Government (Adelaide: Wakefield Press, 1999), 83.

10 Commonwealth, Parliamentary Debates, House of Representatives, 5 May 1992, 2370. 
The most fateful step came with the passage of the Migration Reform Act 1992 (Cth) in late 1992. The Act was passed with Coalition support and came into effect on 1 September 1994. It divided non-citizens into two categories: those with a visa (who were called 'lawful') and those without a visa (who were called 'unlawful'). It then provided that 'unlawful non-citizens' had to be detained until granted a visa or removed from the country. The 273-day time limit that applied to the previous version of mandatory detention was dropped. The legislation also introduced the bridging visa regime. Unlawful non-citizens who met certain criteria could be granted a bridging visa pending the granting of a substantive visa or departure from the country. The grant of a bridging visa made them lawful non-citizens and enabled their release from detention. The bridging visa criteria were such that if a person had become unlawful by overstaying they could get one with ease but if they had entered the country without a visa it was almost impossible to get one.

In 2004, the question of whether a person could be held in immigration detention indefinitely ended up before the High Court of Australia. ${ }^{11}$ $\mathrm{Mr}$ Al-Kateb was a stateless Palestinian who was born and spent most of his life in Kuwait. He arrived in Australia without authorisation and thereby became an unlawful non-citizen subject to detention. After failing in his application for a protection visa, $\mathrm{Mr} \mathrm{Al}-\mathrm{Kateb}$ made a written request to be removed from Australia. However, the Department of Immigration ${ }^{12}$ was unable to find any country prepared to allow him entry. The High Court majority (Justices Callinan, Hayne, Heydon and McHugh) held that the relevant provisions of the Migration Act, by providing that detention of an unlawful non-citizen must continue 'until' the occurrence of one of, at that time, three specified events (that is, grant of a visa, removal or deportation), ${ }^{13}$ had the effect of unambiguously authorising the indefinite detention of unlawful non-citizens in the unfortunate position of neither qualifying for the grant of a visa nor, in practice, being removable/ deportable from Australia in the foreseeable future. Having decided the question of statutory interpretation, the majority judges had to consider whether the statutory provisions were, as argued by the appellant, constitutionally invalid. All four majority judges held that the provisions

11 Al-Kateb v Godwin [2004] HCA 37.

12 The Department of Immigration ceased to exist on 20 December 2017, with its functions being merged into the new Department of Home Affairs. The correct name at the time is used throughout this chapter.

13 A fourth specified event was added when the regional processing arrangements were introduced. 
were constitutionally valid, being an exercise of the power conferred on the Australian Parliament by section 51(xix) of the Constitution to legislate with respect to aliens, which did not infringe the separation of powers between the parliament, the executive and the courts provided for by Chapter III of the Constitution.

Given that the minority judges (Chief Justice Gleeson and Justices Gummow and Kirby) were able to interpret the Migration Act provisions in favour of liberty for $\mathrm{Mr} \mathrm{Al}-\mathrm{Kateb}$, the majority judges were, in fact, making an interpretive choice that hinged on their internalisation of the (white) nationalist ideology written into the Constitution itself. As Greta Bird points out, the language they used was telling. ${ }^{14}$ For example, Justice Callinan (para. 301) referred to the undesirability of giving Mr Al-Kateb 'special advantages because he has managed illegally to penetrate the borders of this country over those who have sought to, but have been stopped before they could do so'. The majority judges were perfectly aware that the conclusion at which they had arrived was incompatible with human rights principles, but they insisted that any remedy lay elsewhere.

The mandatory detention regime was vigorously opposed from the outset by many civil society organisations. Increasing media scrutiny from 2000 also had an effect on public opinion. ${ }^{15}$ In 2005, the then Coalition government introduced residence determinations (colloquially known as 'community detention') to appease members of its own backbench who had started rebelling against the harshness of mandatory detention. ${ }^{16}$ The relevant Migration Act provisions - which are still in effect - give the minister for immigration a personal and non-compellable power exercisable 'in the public interest' to make a determination that a specified person is to reside in a specified place and comply with certain conditions instead of being detained in the manner usually required by the Migration Act. ${ }^{17}$ The purpose of the power is to enable the de facto release ${ }^{18}$ into

14 Greta Bird, 'An Unlawful Non-Citizen Is Being Detained or (White) Citizens Are Saving the Nation from (Non White) Non-Citizens', University of Western Sydney Law Review 9 (2005): 87-110. 15 Savitri Taylor, 'Achieving Reform of Australian Asylum Seeker Law and Policy', Just Policy 24 (2001): 41-54.

16 Savitri Taylor, 'Immigration Detention Reforms: A Small Gain in Human Rights', Agenda: A Journal of Policy Analysis and Reform 13 (2006): 49-62, doi.org/10.22459/AG.13.01.2006.04.

17 Migration Act 1958 (Cth) pt 2 div 7 subdiv B ss 197AA-197AG.

18 As a matter of legal technicality, individuals subject to a residence determination are regarded as being nevertheless in 'immigration detention'. 
the community of unaccompanied minors, families with children and particularly vulnerable adults. As at 26 April 2018, there were 457 people (including 180 children) in community detention in Australia. ${ }^{19}$

Another reform introduced in 2005 was the conferral on the minister for immigration of a personal and non-compellable power exercisable in the public interest' to grant any kind of visa the minister thinks appropriate to a person in immigration detention, even if the person does not fulfil the criteria for grant of a visa of that kind. ${ }^{20}$ In November 2011, in the face of large numbers of so-called unauthorised maritime arrivals, the Labor Government started using this power to grant Bridging Visa Es to most of them $^{21}$ in order to relieve pressure on detention facilities. The Coalition Government continued the practice when it took office in September 2013. As at 26 April 2018, there were 18,027 unauthorised maritime arrivals (including 3,038 children) living in the Australian community on Bridging Visa Es. ${ }^{22}$

Despite the positive reforms made over time to law and policy, as at 26 April 2018, according to the Department of Home Affairs' statistics, there were 1,369 people (including seven children) in Australia's immigration detention facilities. They had been detained an average of 434 days with 264 people having been in detention for over 730 days. ${ }^{23}$ As at 26 April 2018, the longest serving detainee had endured 3,970 days (i.e. over 10 years) in detention. ${ }^{24}$ The fundamental problem remains the continued existence of the legal machinery of mandatory detention, with the non-compellable exercise of ministerial discretion being the only road out for many. Politicians, and the courts, have made it clear that this is a problem and a solution that remain within the purview of Australia's elected representatives.

19 Department of Home Affairs, Immigration Detention and Community Statistics Summary (Canberra: Australian Government Department of Home Affairs, 26 April 2018), available at: www. homeaffairs.gov.au/research-and-stats/files/immigration-detention-statistics-26-april-2018.pdf.

20 Migration Act 1958 (Cth) s 195A.

21 Chris Bowen, 'Bridging Visas to be Issued for Boat Arrivals', media release, 25 November 2011, available at: pandora.nla.gov.au/pan/67564/20120320-0000/www.minister.immi.gov.au/media/cb/ 2011/cb180599.htm.

22 Department of Home Affairs, Immigration Detention and Community Statistics Summary.

23 Ibid.

24 Evidence to Senate Legal and Constitutional Affairs Legislation Committee (SLCALC), Committee Hansard, 21 May 2018 (evidence of Mr Outram, Australian Border Force Commissioner). 


\section{Offshore processing}

From the legal device of 'excised offshore places' to the establishment of detention centres in other countries with which Australia has had colonial relationships, the history of offshore processing is vital to understand if we are to comprehend the fullness of successive Australian governments' approaches to managing the arrival of refugees.

\section{Excision}

In September 2001, in the wake of the Tampa incident ${ }^{25}$ and in the shadow of the terrorist attacks in the United States, the Coalition Government with the support of Labor procured amendments to the Migration Act that defined Christmas Island, Ashmore and Cartier Islands and Cocos (Keeling) Islands to be 'excised offshore places' and allowed for the making of regulations designating other parts of Australia to be 'excised offshore places'. The 2001 amendments also specified that an unauthorised arrival who became an unlawful non-citizen by entering Australia at an 'excised offshore place' was an 'offshore entry person'. The amendments then went on to provide for two things. First, a purported visa application made by an offshore entry person who was an unlawful non-citizen in Australia was invalid unless the minister for immigration exercised a personal and noncompellable power to allow such an application to be made. ${ }^{26}$ Second, an offshore entry person could be kept at an excised offshore place or taken to any 'place outside Australia', including a 'declared country'. ${ }^{27}$

In July 2005, regulations were adopted that effectively designated all parts of Australian territory with the exception of the mainland and Tasmania to be 'excised offshore places'. ${ }^{28}$ In 2006, the Coalition Government tried to go a step further by extending the statutory bar on protection visa applications to all unauthorised maritime arrivals regardless of where they

25 In late August 2001, 433 asylum seekers were rescued from a sinking boat by the Norwegian freighter MV Tampa. The Tampa headed for Christmas Island, but was informed by Australian authorities that the rescued people would not be allowed to disembark there. The Pacific Solution was an outcome of the government's desperate attempts to resolve the ensuing standoff.

26 Migration Act 1958 (Cth) s 46A.

27 These amendments were made by the Migration Amendment (Excision from Migration Zone) Act 2001 (Cth) and the Migration Amendment (Excision from Migration Zone) (Consequential Provisions) Act 2001 (Cth).

28 Migration Regulations 1994 (Cth) reg 5.15C inserted by Migration Amendment Regulations 2005 (No. 6) (Cth). 
first entered Australia. However, Australian civil society organisations mobilised successfully against the Bill intended to accomplish this purpose. $^{29}$ The Senate Legal and Constitutional Affairs Legislation Committee (SLCALC) inquiry into the Migration Amendment (Designated Unauthorised Arrivals) Bill 2006 received 137 submissions but only the Department of Immigration's submission supported the Bill. ${ }^{30}$ The committee's majority report, written by government parliamentarians, recommended that the Bill should not proceed, or in the event that it did proceed, should be very significantly amended to respond to concerns raised during the inquiry and should include an 18-month sunset clause. ${ }^{31}$ The minority and dissenting reports written by the non-government parliamentarians on the committee differed only in their refusal to contemplate an alternative to a complete abandonment of the Bill. The Bill passed the House of Representatives on 10 August 2006, but three government MPs crossed the floor and two abstained from voting. ${ }^{32}$ Although the Coalition had a one-seat majority in the Senate, the prime minister was forced to withdraw the Bill when it became clear that at least one Liberal senator was willing to cross the floor to defeat it. ${ }^{33}$

\section{The 'Pacific Solution'}

By authorising the taking of 'offshore entry persons' to 'declared countries', the 2001 amendments to the Migration Act enabled the lawful implementation of the Pacific Strategy (colloquially known as the 'Pacific Solution') - or so it was thought at the time. ${ }^{34}$ In the same year, Nauru and Papua New Guinea (PNG) were designated as declared countries after their governments had been persuaded to enter into Memoranda of Understanding (MoUs) allowing offshore entry persons to be taken to Australian-controlled facilities in their territory to have any protection

29 Savitri Taylor, 'Australia’s Pacific Solution Mark II: The Lessons to be Learned', UTS Law Review 9 (2007): 106-24.

30 The Bill was introduced into the House of Representatives on 11 May 2006. On the same day, the Senate referred the Bill to the SLCALC for inquiry and report by 13 June 2006. The deadline for submissions was 22 May 2006. The submissions received by the inquiry are available at: www.aph. gov.au/Parliamentary_Business/Committees/Senate/Legal_and_Constitutional_Affairs/Completed_ inquiries/2004-07/migration_unauthorised_arrivals/submissions/sublist.

31 SLCALC, Provisions of the Migration Amendment (Designated Unauthorised Arrivals) Bill 2006 (report, 2006), paras 3.208-3.217.

32 Ross Peake, 'Asylum Bill in Trouble as Senators Waver', Canberra Times, 12 August 2006, 3.

33 Ibid.

34 As explained in the next section, the lawfulness of the first iteration of the Pacific Solution was later cast into doubt by the High Court's decision in Plaintiff M70/2011 v Minister for Immigration and Citizenship. 
claims considered by Australian Department of Immigration officers. It was Coalition Government policy that those found to be refugees would only be resettled in Australia as a last resort if no other country was willing to take them. ${ }^{35}$

The first iteration of the Pacific Solution remained in place from 2001 to 2008. During this period, 1,637 people were taken to Nauru or PNG. ${ }^{36}$ One of them died and another 483 returned voluntarily to their country of origin. ${ }^{37}$ The remaining 1,153 people were resettled in Australia (705), New Zealand (401), Sweden (21), Canada (16), Denmark (6) and Norway (4). ${ }^{38}$

\section{The false spring}

In February 2008 the newly elected Labor Government closed down the processing facilities in Nauru and PNG. In retrospect it seems to have done so only because the number of unauthorised boat arrivals had dwindled substantially since $2001,{ }^{39}$ leading Labor to believe that they were no longer a political problem. In 2009, unauthorised boat arrivals increased dramatically. ${ }^{40}$ Most of those arriving on the boats fell into the definition of 'offshore entry persons' and therefore needed ministerial permission to make a visa application. The government took the boat arrivals to Christmas Island to have their protection claims determined there by the so-called Refugee Status Assessment/Independent Merits Review (RSA/IMR) process, which was a separate and inferior process to the protection visa application process. Only those found to be refugees were given ministerial permission to apply for a protection visa. In Plaintiff M61/2010E \& Others $v$ the Commonwealth of Australia and Others, ${ }^{41}$ however, the High Court held that the RSA/IMR process was not lawful.

35 Savitri Taylor, 'The Pacific Solution or a Pacific Nightmare: The Difference between Burden Shifting and Responsibility Sharing', Asian-Pacific Law and Policy Journal 6 (2005): 1-43.

36 Janet Phillips, 'The "Pacific Solution" Revisited: A Statistical Guide to the Asylum Seeker Caseloads on Nauru and Manus Island' (Background Note, Parliamentary Library, Parliament of Australia, 4 September 2012), available at: www.aph.gov.au/About_Parliament/Parliamentary_Departments/ Parliamentary_Library/pubs/BN/2012-2013/PacificSolution.

37 Ibid.

38 Ibid.

39 Janet Phillips, 'Boat Arrivals and Boat "Turnbacks" in Australia since 1976: A Quick Guide to the Statistics' (Research Papers 2016-17, Parliamentary Library, Parliament of Australia, updated 17 January 2017), available at: www.aph.gov.au/About_Parliament/Parliamentary_Departments/ Parliamentary_Library/pubs/rp/rp1617/Quick_Guides/BoatTurnbacks.

40 Ibid.

41 [2010] HCA 41. 
On 25 July 2011, Australia and Malaysia entered into a legally non-binding Arrangement on Transfer and Resettlement. The arrangement provided for the transfer to Malaysia of up to 800 persons arriving irregularly in Australia by boat after the date of signing. It also stated that, in exchange for Malaysia's assistance, Australia would resettle, over a period of four years, 4,000 UNHCR recognised refugees living in Malaysia at the time of signing. Minister for Immigration Chris Bowen then purported to make Malaysia a 'declared country' using the legal machinery created to implement the Pacific Solution.

Under Migration Act section 198A, 'offshore entry persons' could be taken to any country that the minister for immigration had declared, in writing, to meet three criteria: that it provided asylum seekers with access 'to effective procedures for assessing their need for protection' and protected them pending determination of their refugee status, that it provided protection to refugees pending their voluntary repatriation or resettlement, and that it met 'relevant human rights standards in providing that protection'. The orthodox interpretation of the provision at the time was that the minister's declaration did not have to be true as long as the minister believed it to be true. However, acting on behalf of a man who was to be transferred to Malaysia pursuant to the arrangement with that country, a team of pro bono lawyers coordinated by the Refugee and Immigration Legal Centre swung into action. The team, which had also been responsible for the successful M61 litigation, challenged the orthodox interpretation of section 198A in the High Court and won. ${ }^{42}$

In Plaintiff M70/2011 v Minister for Immigration and Citizenship,${ }^{43}$ a High Court majority (Justice Heydon dissenting) held that section 198A required that a declared country, at a minimum, be bound under international law or their own national laws to provide the protections it specified to asylum seekers and refugees. Since Malaysia did not meet the minimum requirements of section 198A, the High Court's decision invalidated the declaration that the minister had purported to make in respect of it. The reasoning of the majority in $M 70$ cast retrospective doubt on the lawfulness of the Pacific Solution and prospective doubt on the government's ability to take asylum seekers to any country in which they would receive less protection than they would in Australia.

42 Caroline Counsel, 'M70 - The End of Offshore Processing?', LIV President's Blog, 2 September 2011, available at: www.liv.asn.au/LIVPresBlog/September-2011/M70-the-end-of-off-shore-processing. 43 [2011] HCA 32. 
The decisions in $M 61$ and $M 70$ were read by some as a shift by a now differently composed High Court bench away from Al-Kateb and towards a more rights-oriented jurisprudence. And to some extent they were correct. However, because the shift was accomplished through the vehicle of statutory interpretation (i.e. purporting to give effect to the presumed intention of parliament), parliament was handed a trump card. Parliament could now continue to do the work of shaping legislation to circumvent the courts.

\section{Back to the future}

In March 2012, in the wake of its High Court losses in M61 and M70, the Labor Government announced that it would no longer have a parallel processing system for unauthorised boat arrivals. Instead, it would lift the statutory bar on visa applications as a matter of course, enabling such individuals to apply for a protection visa from the outset. ${ }^{44}$ However, Labor was not happy with the situation in which it found itself and, in June 2012, Prime Minister Gillard sought advice on how to 'stop the boats' from an Expert Panel. ${ }^{45}$

In its report released on 13 August 2012, the Expert Panel made 22 recommendations. One of its recommendations was that all unauthorised maritime arrivals, regardless of where they first entered Australia, should be prevented from applying for a protection visa. This was what the Coalition Government had unsuccessfully attempted to do in 2006. In response to the Expert Panel report, the Labor Government made the same attempt and succeeded. The Migration Amendment (Unauthorised Maritime Arrivals and Other Measures) Act 2013 (Cth) entered into force on 1 June 2013.

The Expert Panel also recommended that the government should procure the passage of legislation overturning the High Court decision in $M 70$. It promptly did so. The amendments made to the Migration Act by Migration Legislation Amendment (Regional Processing and Other Measures) Act 2012 (Cth) give the minister for immigration the power to designate

44 Chris Bowen, 'New Single Protection Visa Process Set to Commence', media release, 19 March 2012, available at: web.archive.org/web/20120321130512/www.minister.immi.gov.au/media/cb/2012/ cb184344.htm.

45 The panel consisted of a former chief of the Defence Forces, Angus Houston, a former secretary of the Department of Foreign Affairs and Trade, Michael L'Estrange, and an asylum seeker advocate, Paris Aristotle. 
a country as a 'regional processing country'. Migration Act section 198AD provides that an unauthorised maritime arrival detained in the migration zone must be taken to a regional processing country unless the minister for immigration exercises a personal non-compellable power under section 198AE to exempt the person from being transferred.

Another two recommendations of the Expert Panel were to enter into new asylum seeker processing arrangements with Nauru and PNG. ${ }^{46}$ The panel described the establishment of such arrangements as a 'necessary circuit breaker to the current surge in irregular migration to Australia'. ${ }^{47}$ Again, the government implemented the recommendations with expedition and immediately thereafter the minister for immigration, acting under new Migration Act section 198AB, designated Nauru and PNG as regional processing countries in September and October 2012, respectively.

In the case of Plaintiff S156/2013v Minister for Immigration and Border Protection ${ }^{48}$ the plaintiff tried to argue that Migration Act sections 198AB and 198AD were not supported by any constitutional head of power and were therefore invalid or, in the alternative, that the minister's designation of PNG as a regional processing country was not valid. The High Court held that sections $198 \mathrm{AB}$ and $198 \mathrm{AD}$ were supported by the 'aliens' head of power in section 51(xix) of the Constitution. It also held that the designation of PNG as a regional processing country was perfectly valid. This was just as well for the government, because it was clear that the standards of treatment received by the people transferred to Nauru and PNG had fallen egregiously short of human rights standards from the outset. ${ }^{49}$ The decision in $\$ 156$ was an acknowledgement by the High Court that parliament had played the trump card handed to it in $M 70$. It also underscored that, as intended by the drafters, the Constitution enabled parliament to deal with aliens exactly as it pleased.

46 The Expert Panel also recommended that the transfer provisions of the Malaysian Arrangement should be implemented, after the government had negotiated better human rights safeguards and accountability provisions with Malaysia. Theoretically, the minister for immigration could have done so after designating Malaysia as a regional processing country. However, any such designation would have been disallowed by the Senate because the Coalition opposed implementation of the arrangement for reasons that had more to do with political obstructionism than principle. By contrast, the Coalition had consistently advocated for a return to the Pacific Solution.

47 Expert Panel on Asylum Seekers, Report of the Expert Panel on Asylum Seekers (Canberra: Department of the Prime Minister and Cabinet, August 2012), para. 3.45.

48 [2014] HCA 22.

49 See Ken McPhail, Robert Nyamori and Savitri Taylor, 'Escaping Accountability: A Case of Australia’s Asylum Seeker Policy,' Accounting, Auditing \& Accountability Journal 29 (2016): 947-84, doi.org/10.1108/AAAJ-03-2014-1639 and sources cited therein. 
On 19 July 2013, not long after replacing Julia Gillard as prime minister following an internal challenge, Kevin Rudd held a joint press conference with Peter O'Neill, the prime minister of PNG. At the press conference, it was announced that asylum seekers arriving in Australia by boat after that date would have 'have no chance of being settled in Australia as refugees'. ${ }^{50}$ The MoUs with Nauru and PNG were subsequently updated to facilitate the implementation of what Rudd admitted was 'a very hardline decision' intended to deter people smuggling. ${ }^{51}$ I will return to this history of 'processing' in PNG and in Nauru below.

\section{Operation Relex and Operation Sovereign Borders}

In the aftermath of the Tampa incident, the Howard Coalition Government instituted Operation Relex to prevent unauthorised arrivals from entering Australian waters. Between October and December 2001, four vessels were intercepted at sea by the Australian navy and escorted back towards Indonesia. ${ }^{52}$ The navy also attempted to turn back three other vessels in 2001. All sank at some point during the course of interception and were towed back towards Indonesia, though mercifully all but two of the passengers were successfully rescued. The fifth and final tow back of the Howard Government period took place in November 2003. ${ }^{53}$

The Abbott Coalition Government came into power in September 2013 on a platform that included a pledge to put an end to the resurgence of boat arrivals. Immediately upon taking office, the Coalition Government implemented the military-led Operation Sovereign Borders, which involved, among other things, the turn-back of unauthorised maritime arrivals to their most recent country of departure (usually Indonesia) or, in the case of those arriving directly from their country of origin, handing back to country of origin authorities. In theory, an exception is made for those found in a screening interview to have prima facie protection claims. Unauthorised maritime arrivals screened-in pursuant to this process are supposed to be taken to a regional processing country instead

50 Kevin Rudd, 'Transcript of Joint Press Conference', Press Office, Prime Minister of Australia, 19 July 2013, available at: webarchive.nla.gov.au/awa/20130730234007/pandora.nla.gov.au/ pan/79983/20130731-0937/www.pm.gov.au/press-office/transcript-joint-press-conference-2.html.

51 Ibid.

52 Senate Select Committee on a Certain Maritime Incident, Report of the Senate Select Committee on a Certain Maritime Incident (Canberra: Parliament of Australia, 2002), para 2.74.

53 Savitri Taylor, 'Towing Back the Boats: Bad Policy Whatever Way You Look at It', The Conversation, 12 June 2013, available at: theconversation.com/towing-back-the-boats-bad-policy-whatever-way-youlook-at-it-15082. 
of being turned back or handed back. Between the commencement of Operation Sovereign Borders and 21 May 2018, 800 people on 32 boats had been intercepted at sea. ${ }^{54}$ Of those only two people had been screened-in - both in $2014 .{ }^{55}$ In addition, 157 Sri Lankan passengers on a vessel departing from India, which was intercepted in late June $2014,{ }^{56}$ were transferred to Nauru on 2 August 2014 after a brief sojourn on the Australian mainland. ${ }^{57}$ These individuals had not actually been screenedin; rather, Australia had tried but failed to convince Indian or Sri Lankan authorities to take them. In any event, the screen-in figures give rise to the strong inference that the screening process is, at best, unreliable or, at worst, cynical window-dressing.

\section{The Nauru arrangement}

As of August 2018, the arrangement with $\mathrm{Nauru}^{58}$ means that 'unauthorised maritime arrivals' can be transferred to Nauru for processing of asylum claims by the Nauruan Government. As mentioned above, the most recent transfer took place in 2014. In theory, the processing centre in Nauru in which those transferred were detained until October $2015^{59}$ and in which some still reside, ${ }^{60}$ is run by the Nauruan Government. However,

54 Evidence to SLCALC, Committee Hansard, 21 May 2018 (evidence of Air Vice Marshal Osborne). 55 One passenger out of 41 arriving on a boat from Sri Lanka in late June 2014 was screenedin but elected to be repatriated with the others: Scott Morrison, 'Australian Government Returns Sri Lankan People Smuggling Venture', media release, 7 July 2014, available at: webarchive.nla.gov.au/ gov/20140801014043/www.minister.immi.gov.au/media/sm/2014/sm216152.htm. Another passenger out of 38 arriving by boat from Sri Lanka in mid-November 2014 was also screened-in: Scott Morrison, 'People Smuggling Venture Returned to Sri Lanka', media release, 29 November 2014, available at: webarchive.nla.gov.au/gov/20141215053228/www.minister.immi.gov.au/media/sm/2014/sm219651. htm. Interestingly, Air Vice Marshal Osborne's evidence to the SLCALC on 21 May 2018 was that only one person had been screened-in during the period.

56 Department of Immigration, Annual Report 2014-2015 (Australian Commonwealth Department of Immigration, 2015), 209.

57 Scott Morrison, 'Transfer of 157 IMAs from Curtin to Nauru for Offshore Processing', media release, 2 August 2014, available at: webarchive.nla.gov.au/gov/20141215053416/www.minister. immi.gov.au/media/sm/2014/sm216855.htm.

58 Memorandum of Understanding between the Republic of Nauru and the Commonwealth of Australia, Relating to the Transfer to and Assessment of Persons in Nauru, and Related Issues, signed 3 August 2013, available at: dfat.gov.au/geo/nauru/pages/memorandum-of-understanding-between-the-republic-ofnauru-and-the-commonwealth-of-australia-relating-to-the-transfer-to-and.aspx.

59 The processing centre in Nauru was made an open centre in October 2015: Joyce Chia and Asher Hirsch, 'Did "Ending” Detention on Nauru Also End the Constitutional Challenge to Offshore Processing?', The Conversation, 9 October2015, available at: theconversation.com/didending-detention-on-nauru-also-end-the-constitutional-challenge-to-offshore-processing- 48667 .

60 As at 21 May 2018, 253 people resided in the processing centre: evidence to SLCALC, Committee Hansard, 21 May 2018 (evidence of Ms Newton, Department of Home Affairs). 
all the work is done by organisations contracted, instructed and paid by the Australian Government. These arrangements have been challenged by successive court cases. All, however, have failed, with the government changing the relevant legislation to deal with any breaches, or potential breaches, identified by the High Court. ${ }^{61}$

\section{The PNG arrangement}

Similarly, the current $\mathrm{MoU}$ with $\mathrm{PNG}^{62}$ provides for the transfer of 'unauthorised maritime arrivals' to PNG for processing of asylum claims by the PNG Government. The most recent transfer to PNG took place in $2014 .{ }^{63}$ As in the case of the processing centre in Nauru, the processing centre on Manus Island in PNG, which until recently was used to house those transferred, was run, in theory, by the PNG Government. However, as in the case of Nauru, all the work was done by organisations contracted, instructed and paid by the Australian Government.

On 26 April 2016, the PNG Supreme Court ruled that amendments to the PNG Constitution intended to enable the detention of those transferred at the processing centre were invalid and that such detention was therefore unconstitutional and illegal. ${ }^{64}$ Following this, the PNG Government made the decision that the Manus Island processing centre would be closed. In April 2017, the two governments agreed to work towards a closing date of 31 October 2017. When this date came around, despite resistance by centre residents, ${ }^{65}$ the foreshadowed closure of the Manus Island centre took place as planned.

61 See, for example, Nicole Hasham, 'High Court Finds Offshore Detention Lawful', Sydney Morning Herald, 3 February 2016, available at: www.smh.com.au/politics/federal/high-court-findsoffshore-detention-lawful-20160203-gmk5q6.html.

62 Memorandum of Understanding between the Government of the Independent State of Papua New Guinea and the Government of Australia, Relating to the Transfer to, and Assessment and Settlement in, Papua New Guinea of Certain Persons, and Related Issues, signed 6 August 2013, available at: dfat.gov. au/geo/papua-new-guinea/pages/memorandum-of-understanding-between-the-government-of-theindependent-state-of-papua-new-guinea-and-the-government-of-austr.aspx.

63 Evidence to SLCALC, Committee Hansard, 21 May 2018 (evidence of Air Vice Marshal Osborne).

64 Namah v Pato [2016] PGSC 13.

65 This resistance is described and its rationale explained in Behrouz Boochani, 'A Letter from Manus Island', Saturday Paper, 9 December 2017, available at: www.thesaturdaypaper.com.au/news/ politics/2017/12/09/letter-manus-island/15127380005617. 


\section{Durable solutions?}

The MoU with PNG provides that 'Transferees' recognised by it as refugees will be settled in PNG or elsewhere but not in Australia. As at 22 May 2017, only 38 recognised refugees had chosen to settle in PNG. ${ }^{66}$ The MoU with Nauru also provides for the possibility that 'Transferees' recognised by it as refugees will be settled in that country, subject to the case-by-case agreement of the Nauruan Government. Thus far, however, the most that Nauru has been prepared to grant to those whom it has recognised as refugees is permission to remain in Nauru for 20 years. ${ }^{67}$

\section{According to The Guardian:}

Over the past five years, Australia has approached dozens of countries - including Kyrgyzstan - offering millions of dollars and other inducements in exchange for resettling some refugees from Australia's camps. ${ }^{68}$

Thus far it has only had two successes.

On 26 September 2014, the Australian Government signed a four-year $\mathrm{MoU}$ with the Cambodian Government providing for the voluntary resettlement in Cambodia of people recognised as refugees by Nauru. ${ }^{69}$ As at the time of writing, seven refugees had resettled in Cambodia ${ }^{70}$ but four of them had subsequently returned to their countries of origin. ${ }^{71}$

On 13 November 2016, the Australian Government announced that unauthorised maritime arrivals, who had already been transferred to Nauru or PNG, would be considered for refugee resettlement in the

66 Evidence to SLCALC, Committee Hansard, 22 May 2017 (evidence of Ms Newton, Department of Immigration).

67 Department of Immigration, Answer to Question Taken on Notice AE17/213, Additional Estimates Hearing: 27 February 2017, available at: www.aph.gov.au/ /media/Committees/legcon_ ctte/estimates/add_1617/DIBP/QoNs/AE17-213.pdf.

68 Ben Doherty, 'Australia’s Refugee Deal “a Farce” after US Rejects All Iranian and Somali Asylum Seekers', Guardian, 8 May 2018, available at: www.theguardian.com/australia-news/2018/may/08/ australias-refugee-deal-a-farce-after-us-rejects-all-iranian-and-somali-asylum-seekers.

69 Memorandum of Understanding between the Government of the Kingdom of Cambodia and the Government of Australia, Relating to the Settlement of Refugees in Cambodia, signed 26 September 2014, available at: www.refworld.org/docid/5436588e4.html.

70 Evidence to SLCALC, Committee Hansard, 21 May 2018 (evidence of Ms Geddes, Department of Home Affairs).

71 Erin Handley, 'Nauru Refugee Quietly Arrives', Phnom Penh Post, 25 May 2017, available at: www.phnompenhpost.com/national/nauru-refugee-quietly-arrives. 
United States by officials of that country upon referral by UNHCR. ${ }^{72}$ As at 21 May 2018, the United States had accepted 372 refugees for resettlement and actually resettled 249 of them (165 from Nauru and 84 from PNG) ${ }^{73}$ However, it had also vetted and refused resettlement to a further 121 recognised refugees, including 70 Iranians. $^{74}$

Since the recommencement of offshore processing, three refugees have managed to arrange resettlement for themselves in Canada. ${ }^{75}$ Australia has so far resisted taking up a longstanding offer from New Zealand to resettle 150 refugees in case those resettled in New Zealand take advantage of the Trans-Tasman Travel Arrangement to relocate to Australia at a later date. ${ }^{76}$ However, it has not entirely closed the door on the offer. ${ }^{77}$

As at 21 May 2018, 939 of the people, including women and children, transferred by Australia to Nauru were still in Nauru. ${ }^{78}$ As at the same date, 716 of the people transferred by Australia to PNG were still in PNG. ${ }^{79}$ A further 460 people, who had previously been transferred to Nauru or PNG, were in Australia after being brought there for the purpose of medical treatment. ${ }^{80}$ Individuals in this last group are expected to return to Nauru or PNG as the case may be upon completion of treatment, though they often refuse to do so.

It is not clear exactly how many of the 2,115 people still subject to the offshore processing arrangements as at 21 May 2018 were recognised refugees. However, given the recognition rates of 87 per cent in Nauru

72 Peter Dutton, 'Joint Press Conference with the Prime Minister, Maritime Border Command, Canberra' [transcript], The Hon Peter Dutton MP Minister for Immigration and Border Protection, 13 November 2016, available at: web.archive.org/web/20170307202401/www.minister.border.gov. $\mathrm{au} /$ peterdutton/Pages/press-conference-with-the-minister-for-immigration-and-border-protectionmaritime-border-command.aspx.

73 Evidence to SLCALC, Committee Hansard, 21 May 2018 (evidence of Ms Geddes, Department of Home Affairs).

74 Ibid.

75 Ibid. (evidence of Mr Pezzullo, Secretary, Department of Home Affairs).

76 Ibid.

77 Peter Dutton, 'Doorstop Interview, Parliament House' [transcript], The Hon Peter Dutton MP Minister for Home AffairslMinister for Immigration and Border Protection, 24 May 2018, available at: web.archive.org/web/20180821025013/minister.homeaffairs.gov.au/peterdutton/Pages/ Interview-Parliament-House.aspx.

78 Evidence to SLCALC, Committee Hansard, 21 May 2018 (evidence of Ms Newton, Department of Home Affairs).

79 Ibid. (evidence of Ms Geddes, Department of Home Affairs).

80 Ibid. (evidence of Ms Dunn, Department of Home Affairs). 
and 74 per cent in $\mathrm{PNG},{ }^{81}$ the majority would be. Even if the United States allocates the remainder of the 1,250 resettlement places it has put on the table, a large number of refugees will be left without the prospect of a durable solution in the foreseeable future.

\section{A reflection}

Australia did not get to where it currently is all at once but step by incremental step. Some of those steps were taken by Labor governments, others were taken by Coalition governments, but except for a period from 2004 to 2007 when the Coalition controlled both houses of parliament, the legislative steps at least could not have been taken without the support of non-government politicians. The most insidious thing about every step taken was that it became the new normal and brought the next step into the realm of conceivable. The upshot was that most politicians in the two major parties were able, at every crucial point along the 25-plusyear journey, to rationalise taking just that one step more for the sake of winning or at least not losing the ongoing struggle for political power.

It is possible through litigation to get Australian courts to adjudicate on the lawfulness of executive action and to award enforceable remedies for breaches of the law. As illustrated above, however, in the migration jurisdiction the usual reaction when the government of the day does not agree with a judicial decision is to seek passage of legislation overturning the decision as a precedent for the future. Usually, too, the government is able to muster the parliamentary numbers necessary to succeed in such attempts. The only scenario in which the courts have the upper hand is in the interpretation of the Australian Constitution. However, as interpreted by the courts, the Constitution does not place many limits on the executive government or the parliament. So far, just about everything that the government and parliament have done in relation to asylum seekers and refugees has passed the constitutionality test. My depressing conclusion is that the stain of Australia's original sin remains, tainting the present and future. Because of Australia's constitutional beginnings, Australians cannot rely on their existing legal and political structures to deliver them from evil.

81 Australian Border Force, 'Operation Sovereign Borders Monthly Update: October 2017', Australian Border Force Newsroom, 14 November 2017, available at: newsroom.abf.gov.au/channels/ Operation-Sovereign-Borders/releases/a4e1949e-3a4b-4750-bc65-cda9b3a668d1. These percentages are from 31 October 2017, on which date the Australian Government stopped updating the statistics. 
This text is taken from Refugee Journeys: Histories of Resettlement, Representation and Resistance, edited by Jordana Silverstein and Rachel Stevens, published 2021 by ANU Press, The Australian National University, Canberra, Australia.

doi.org/10.22459/RJ.2021.09 